\title{
Analysis of supporting indicators for innovation in Romania compared to neighboring EU countries
}

\author{
Bungau Constantin ${ }^{1, *}$, Gherghea Ion Cosmin ${ }^{1}$ \\ ${ }^{1}$ University of Oradea, Engineering and Management Department, Romania
}

\begin{abstract}
The paper presents a comparative study of indicators which targeting the facilities and support for the innovation process. The study targets indicators regarding human resources, support structure / infrastructure and legislative provisions. The analysis is carried out over the last 5 years, comparing the indicators in Romania and the neighboring countries (Bulgaria, Hungary, Austria, Slovakia and Poland) and highly developed countries (Germany and France). Based on this study, will be drawing conclusions for improvement of these indicators. The indicators that will be taken into consideration are: Availability of scientists and engineers, Researchers, Quality of the education system, Researchers in Research and Development, Research and development expenditure, Firm-level technology absorption, University-industry collaboration in Research \& Development, Quality of scientific research institutions, Gross domestic spending on Research and Development, Property rights, Intellectual property protection.
\end{abstract}

\section{Introduction}

There is a significant distinction between invention and innovation. The invention is the process of creating a new idea or a new concept, while innovation is transforming the new concept into a commercial success. In conclusion, the applied invention is an innovation. The innovation process starts from identifying an existing problem, looking for new solutions that then implement it contributes to increasing profitability and competitiveness. [1]

Innovation has an important role in the development of a society, as Tim Stock et all considers that innovation is the "growth engine" of society. In the same paper Tim Stock defines innovation as a multi-stage process, and creativity, motivation and knowledge are the main factors leading to the first phase of innovation. [2].

The literature presents various studies that measure the innovation performance in Romania. [3-6].

\section{Research methodology}

In order to carry out this study, there were analysed 11 indicators that aim and support the innovation process, which were structured in 3 groups: human resources, structure support / infrastructure and legislative provisions (according to Table 1). Statistical data was accessed from the World Bank website [7]. The analysis of the indicators has been carried out over the last 5 years, comparing the indicators of Romania with the neighboring countries (Bulgaria, Hungary, Austria, Slovakia and Poland) and the highly developed countries (Germany and France). As a result of data processing, have been generated line graphs that show the upward or downward trend in the last 5 years of each indicator [7].

Table 1. Structuring the analyzed indicators on three groups [7].

\begin{tabular}{|c|c|c|}
\hline Groups & Indicators & Acronym \\
\hline \multirow{4}{*}{$\begin{array}{l}\text { Human } \\
\text { resources }\end{array}$} & $\begin{array}{l}\text { Availability of scientists and } \\
\text { engineers }\end{array}$ & ASE \\
\hline & Researchers & $\mathrm{R}$ \\
\hline & $\begin{array}{l}\text { Quality of the education } \\
\text { system }\end{array}$ & QES \\
\hline & Researchers in R\&D & RRD \\
\hline \multirow{5}{*}{$\begin{array}{c}\text { Support } \\
\text { structure / } \\
\text { Infrastructure }\end{array}$} & $\begin{array}{l}\text { Research and development } \\
\text { expenditure (\% of GDP) }\end{array}$ & RDE \\
\hline & $\begin{array}{l}\text { Firm-level technology } \\
\text { absorption }\end{array}$ & FLTA \\
\hline & $\begin{array}{l}\text { University-industry } \\
\text { collaboration in Research \& } \\
\text { Development }\end{array}$ & UICRD \\
\hline & $\begin{array}{l}\text { Quality of scientific } \\
\text { research institutions }\end{array}$ & QSRI \\
\hline & $\begin{array}{l}\text { Gross domestic spending on } \\
\text { R\&D }\end{array}$ & GDSRD \\
\hline \multirow{2}{*}{$\begin{array}{l}\text { Legislative } \\
\text { provisions }\end{array}$} & Property rights & PR \\
\hline & $\begin{array}{l}\text { Intellectual } \\
\text { protection }\end{array}$ & IPP \\
\hline
\end{tabular}

\section{Data analysis}

\subsection{Group 1 - Human resources}

\subsubsection{Availability of scientists and engineers (ASE)}

In 2013, Romania ranks last in terms of the ASE indicator, registering a score of 3.64 on a scale of 1 to 7 , but it can

* Corresponding author: bungau@uoradea.ro 
see a slight increase by 2015 , when it scored 4.13 , after which it drops slightly by 2017 , recording a score of 3.78 , but keeping it higher than in 2013. Although Romania has declined by the past two years, there is an increase in the hierarchical level. From the last ranked in 2013, in 2017 it climbed to 5 th place in the 8 countries analyzed. In 2017 it is worth noting the high level of Germany which registered a significant increase, surpassing Romania by $36.24 \%$.

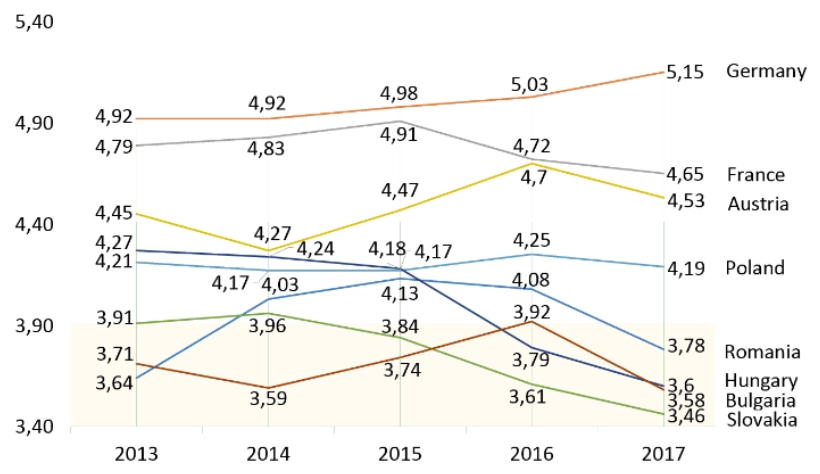

Fig. 1. Availability of scientists and engineers (ASE) [7]

\subsubsection{Researchers (R)}

Regarding $\mathrm{R}$ indicator, we analyzed the available data onto the last 5 years, namely the period 2011-2015. Data onto Bulgaria is missing from this study. This indicator is measured taking into account the number of researchers per 1000 employees. It is also important to note that the data are incomplete in some analyzed countries, according to the chart below. Taking these issues into account, the situation in 2013, the year in which the values of each analyzed country (with the exception of Bulgaria) are identified. In 2013, Romania ranks 6th, registering a score of 27.6. Germany ranks first with 549.28 points, with $49.95 \%$ above second place (France) and $1890.14 \%$ more than Romania, which is a big difference between the two countries.

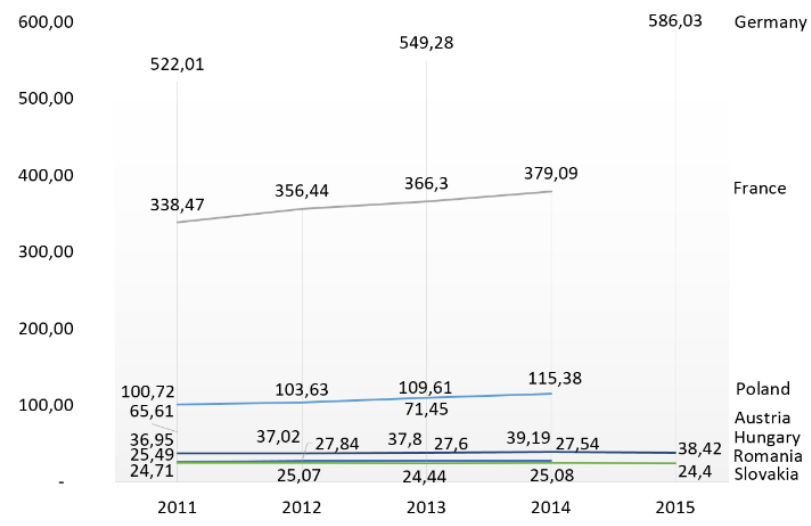

Fig. 2. Researchers (R) [7]

\subsubsection{Quality of the education system (QES)}

In 2013, Romania ranks 7th in terms of QES indicator, at a close distance from Poland, Hungary and Bulgaria, recording a score of 3.25 on a scale of 1 to 7 , and in 2014 it is ranked 4th, then decreasing easy, going down to 7 th in 2017.

In terms of QES, in 2017 Germany leads the standings ranking, being at the top of the ranking with a score of 5.37, followed by France and Austria. Compared with Romania, Germany is $91.78 \%$ above Romania.

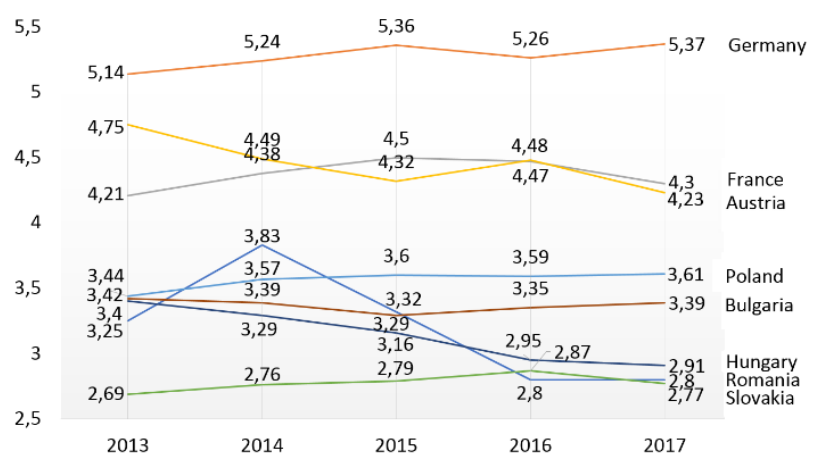

Fig. 3. Quality of the education system (QES) [7]

\subsubsection{Researchers in R\&D (RRD)}

Starting from 2010 until 2014, Romania ranks last in terms of RRD indicator. In 2014, register a scores of 0.92 on a scale of 1 to 7 , with $98.91 \%$ below Bulgaria which is the next ranked. The top 3 positions are Austria with a score of 4.81 , followed by Germany with 4.38 and France with 4.2.

Compared with Romania, the first ranked Austria is above Romania with $422.82 \%$.

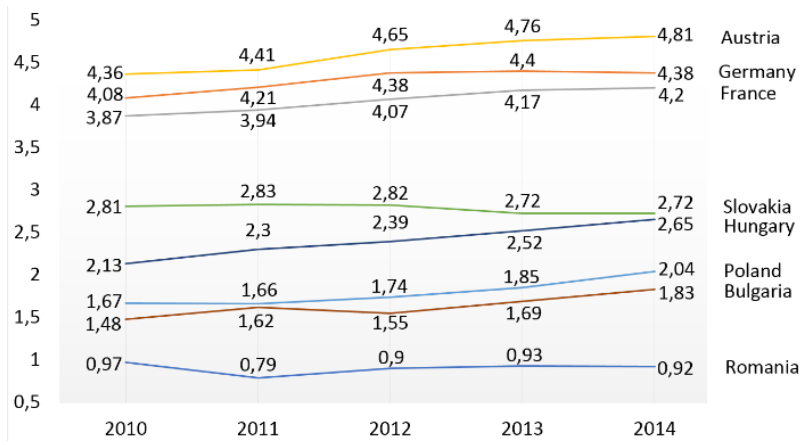

Fig. 4. Researchers in R\&D (RRD) [7]

\subsection{Group 2 - Support structure/ Infrastructure}

\subsubsection{Research and development expenditure (RDE)}

Starting from 2010 to 2014, Romania ranks last in terms of RDE indicator. In 2014, registering a scores of 0.38 on a scale of 1 to 7 , with $110.52 \%$ below Bulgaria which is the next ranked. The first 3 positions are Austria with 2.99 , followed by Germany with 2.87 , and 3rd place France with 2.26.

Compared with Romania, the first ranked Austria is above Romania with $686.84 \%$. 


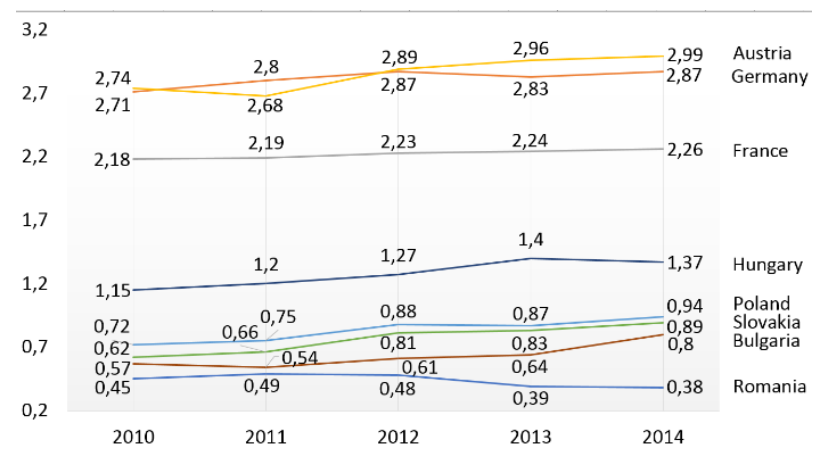

Fig. 5. Research and development expenditure (\% of GDP) (RDE) [7]

\subsubsection{Firm-level technology absorption (FLTA)}

In 2012, Romania ranks 7th from 8 countries in terms of FLTA indicator, recording a score of 4.05 on a scale of 1 to 7 , but it can see a slight increase until 2015 when recording a score of 4.44, maintaining the same level in 2016 (the last year analyzed), surpassing Poland and Bulgaria, thus rising to the 6th place.

On the first 3 positions are Germany with 5.74, followed by Austria with 5.68, and 3rd place is France with a score of 5.45 .

Compared with Romania, the first ranked Germany is $29.27 \%$ above Romania.

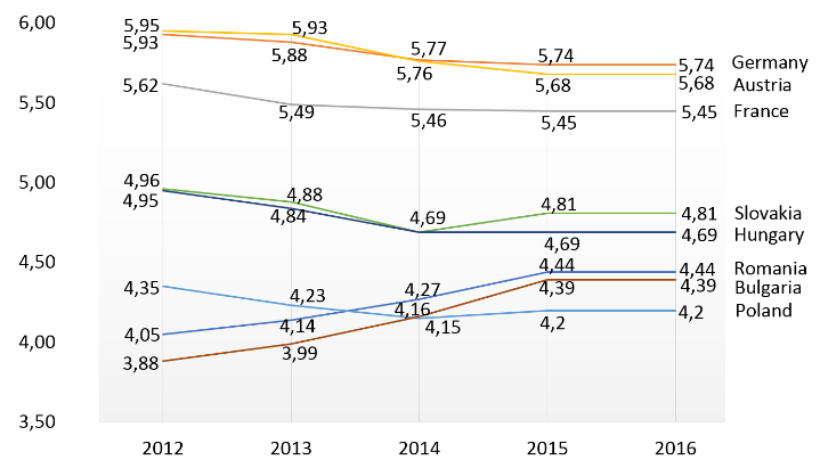

Fig. 6. Firm-level technology absorption (FLTA) [7]

\subsubsection{University-industry collaboration in Research \& Development (UICRD)}

In 2013, Romania ranks 6th out of 8 countries in the UICRD indicator, registering a score of 3.33 on a scale of 1 to 7 , then in 2014 and 2015 has increased to 3.59, and then dropped on the last place in 2017, reaching a score of 3.14. Compared to the neighboring countries it is at a relatively small distance.

On the first 3 positions are Germany with 5.37, followed by Austria with 4.81, and third place is France with a score of 4.22 .

Compared to Romania, the first ranked, Germany, is with $71.01 \%$ above Romania.

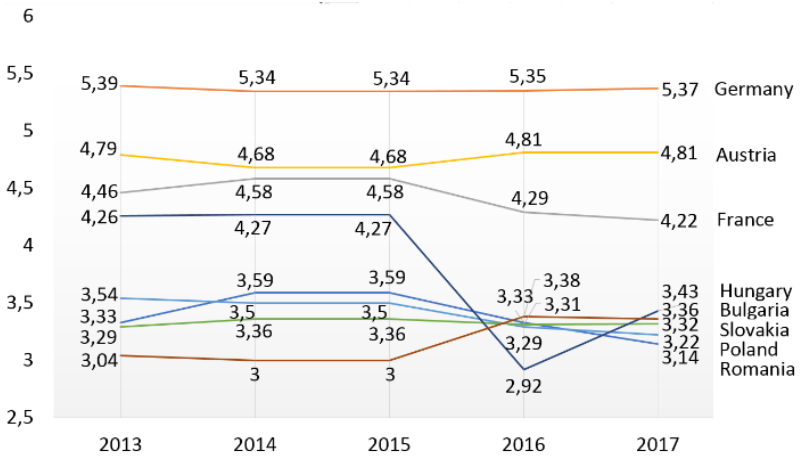

Fig. 7. University-industry collaboration in Research \& Development (UICRD) [7]

A detailed study of university-industry collaboration in Research \& Development is presented in publications 8 and $9[8,9]$.

\subsubsection{Quality of scientific research institutions (QSRI)}

In 2013, Romania ranks 6th in terms of QSRI indicator, registering a score of 3.74 on a scale of 1 to 7 , and the next year rose slightly overtaking Poland, then dropped to 7 th. In 2017 it is again on the 6th place with a score of 3.98 , surpassing Bulgaria and Slovakia.

On the first three positions are France with a score of 5.78, followed by Germany with 5.67, and Austria with a score of 5.36 .

Compared with Romania, the first ranked France is with $45.22 \%$ above Romania.

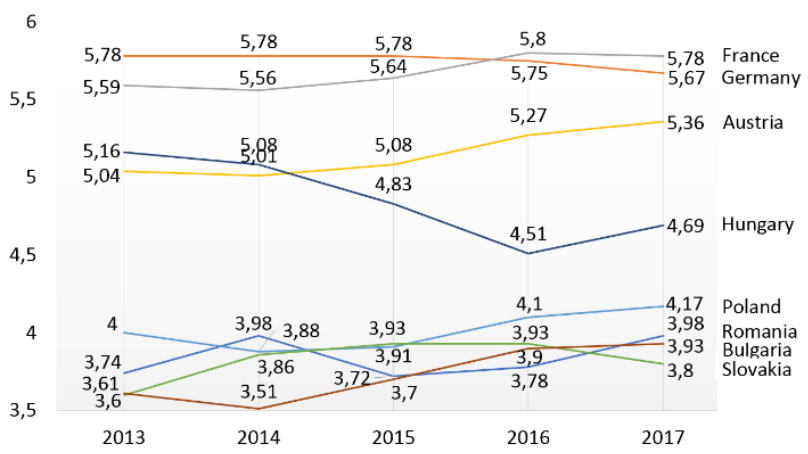

Fig. 8. Quality of scientific research institutions (QSRI) [7]

\subsubsection{Gross domestic spending on R\&D (GDSRD)}

Regarding the GDSDR indicator, it was analyzed the available datas onto the last 5 years (2011-2015). This indicator is measured in millions of USD and as a percentage of GDP. It is also important to note that the data onto Bulgaria are missing from this indicator.

In the first analysis, in 2011, Romania ranked 6th out of the 7 analyzed countries, registering a score of 1.67 over Slovakia.

In 2015 Germany leads the ranking with a score of 101.68 , over the place occupied by France with $86.56 \%$, and compared to Romania is over $5195.83 \%$, representing a very large difference between the two countries. 


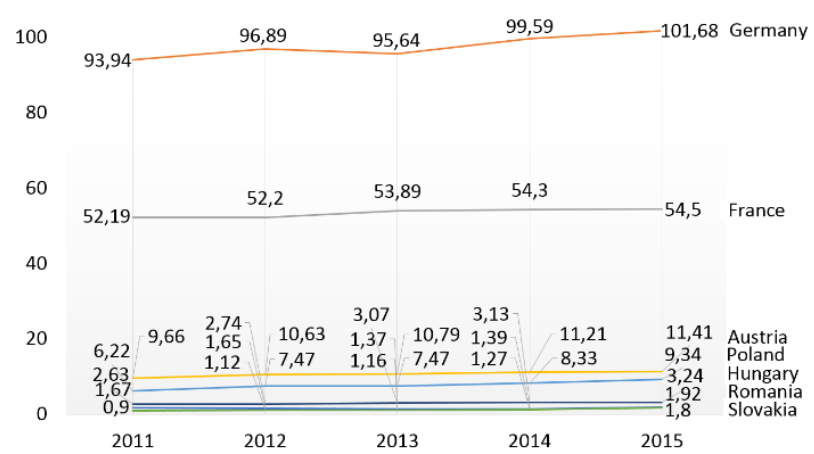

Fig. 9. Gross domestic spending on R\&D (GDSRD) [7]

\subsection{Group 3 - Legislative provisions}

\subsubsection{Property rights (PR)}

In 2013, Romania ranks 5th in terms of PR indicator, registering a score of 3.94 on a scale of 1 to 7 , at the same level as Slovakia.

In the following year, 2014, registered a slight increase exceeding Slovakia, then dropped in 2015, then rose slightly until 2017 , registering a score of 4.38 points when it surpassed Slovakia and Poland, ranked 4th and also topped the reported ranking to the neighboring countries. On the first three positions are Austria with a score of 5.86 , followed by Germany with 5.56, and 3rd place is France with a score of 5.37.

Compared with Romania, the first ranked Austria is with $33.78 \%$ above Romania.

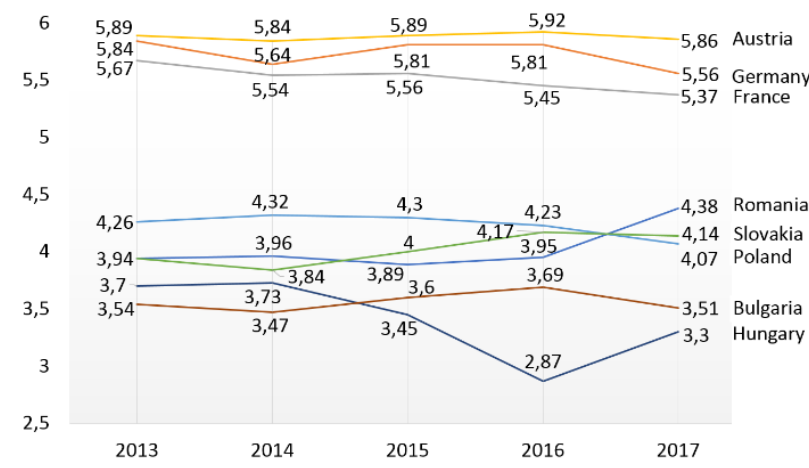

Fig. 10. Property rights (PR) [7]

\subsubsection{Intellectual property protection (IPP)}

In 2013, in terms of IPP indicator, Romania ranks last from the eight countries analyzed, registering a score of 2.9 on a scale from 1 to 7 .

In the following year, 2014 grew slightly beyond Bulgaria, after which it climbed steadily until 2017 when it surpassed all of neighboring countries, being ranked among 4th and also topping the ranking of neighboring countries, recording a score of 4.59 .

On the top three positions are Austria with a score of 5.91, followed by France with 5.82, and Germany with 5.74. In comparison with Romania, the first ranked Austria, is with $28.75 \%$ above Romania.

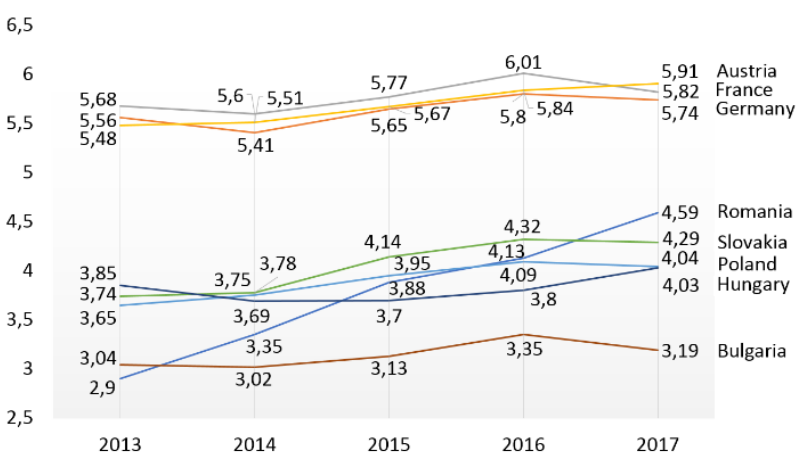

Fig. 11. Intellectual property protection (IPP) [7]

\section{Conclusions}

The objective of this study was to analyze the 11 indicators that aim and support the innovation process, which were structured in 3 groups, namely human resources, structure support / infrastructure and legislative provisions.

Conclusion Group 1 - Human resources

In terms of the ESA indicator, Romania is ranked 5th in the eight countries analyzed. Compare with the first ranked, Germany, Romania is over $36.24 \%$. As for the comparison of Romania with the neighboring countries, Romania is located above Slovakia, Bulgaria and Hungary, but under Poland with 10.84\%.

From the point of view of the $\mathrm{R}$ indicator, from the 8 countries analyzed, Romania ranks 6th. Compare with the first ranked, Germany, Romania is surpassed by $1890.14 \%$. Regarding the comparison of Romania with the neighboring countries, Romania is situated above Slovakia, being overtaken by the other neighboring countries.

In terms of the QES indicator, out of the 8 countries analyzed, Romania ranks 7th. Compare with the first ranked, Germany, Romania is surpassed by $91.78 \%$. Regarding the comparison of Romania with the neighboring countries, Romania is located above Slovakia, but under Hungary, Bulgaria and Poland. As for Poland, the top of the ranking among the neighboring countries Romania is at a distance of $28.92 \%$.

From the point of view of the RRD indicator, out of the 8 analyzed countries, Romania ranks last. Compare with the first-ranked, Austria, Romania is surpassed with $422.82 \%$. Regarding the comparison of Romania with the neighboring countries, Romania is located under all of the neighboring countries. Slovakia, the first ranked among the neighboring countries, Romania is at a distance of $195.65 \%$.

From the point of view of human resources, Romania is best positioned to the ASE indicator, ranking 5th out of the 8 analyzed countries, and the weakest indicators is RRD.

The biggest difference between Romania and the first ranked country in the 1st group is the Resource (R) indicator, where Germany records a rate of $1890.14 \%$ above Romania.

Conclusion Group 2 - Support structure/Infrastructura 
From the point of view of the RDE indicator, out of the eight analyzed countries, Romania ranks last. Compare with the first-ranked, Austria, Romania is surpassed with $686.84 \%$. Compare with the neighboring countries, Romania is situated under all of the neighboring countries. Compared with Hungary which is on top of the ranking among the neighboring countries, Romania is at a distance of $260.52 \%$.

In terms of the FLTA indicator, out of the 8 countries analyzed, Romania ranks 6th. Compare with the first ranked, Germany, Romania is surpassed with $29.27 \%$. Regarding the comparison of Romania with the neighboring countries, Romania is located above Bulgaria and Poland, but under Hungary and Slovakia. Slovakia, at the top of the ranking among the neighboring countries, compared to Romania is at a distance of $8.33 \%$

In terms of the UICRD indicator, out of the 8 analyzed countries, Romania ranks last. Compare with the firstranked, Germany, Romania is surpassed with $71.01 \%$. Compared with the neighboring countries, Romania is situated under all of the neighboring countries, regarding Hungary, which is on top of the ranking among the neighboring countries, Romania is at a distance of $9.23 \%$. Romanian researchers have a very high potential (many new methods and applications are published in relevant specialist journals, but the major problem is the low financial capacity of universities to promote inventions, to be taken over and then applied on a large scale in production, industry, agriculture, etc.) $[10,11,12]$.

In terms of the QSRI indicator, out of the 8 countries analyzed, Romania ranks 6th. Compare with the first ranked, France, Romania is surpassed with $45.22 \%$. Compared with the neighboring countries, Romania is located above Slovakia and Bulgaria, but under Hungary and Poland, Regarding Hunagry which is on the top of the ranking among the neighboring countries, Romania is at a distance of $17.83 \%$.

In terms of the GDSRD indicator, out of the 7 analyzed countries (because the data for Bulgaria are missing), Romania is ranked 6th. Compare with the first ranked, Germany, Romania is surpassed with $5195.83 \%$ (wich is a big difference). As for the comparison of Romania with the neighboring countries, Romania is situated above Slovakia, but under the other neighboring countries, and compared to Poland which is on the top of the ranking among the neighboring countries, Romania is at a distance of $386.45 \%$.

In terms of Support structure, Romania is best placed to the FLTA and QSRI indicators, ranking 6th out of the 8 analyzed countries, and the worst indicators are RDE and UICRD.

The biggest difference between Romania and the first ranked country within Group 2 is indicator 7, Gross domestic expenditure on R \& D (GDSRD), where Germany records a $5195.83 \%$ over Romania.

Conclusion Group 3 - Legislative provisions

From the point of view of the PR indicator, out of the 8 countries analyzed, Romania ranks 4th. Compare with the first ranked, Austria, Romania is surpassed with $33.78 \%$. Compare with the neighboring countries, Romania is located above all of neighboring countries, surpassing the next neighboring country, Slovakia with 5.79\%.
From the point of view of the IPP indicator, out of the 8 countries analyzed, Romania ranks 4th. Compare with the first ranked, Austria, Romania is surpassed with $28.75 \%$. Regarding the comparison of Romania with the neighboring countries, Romania is located above all the neighboring countries, surpassing the next neighboring country, Slovakia with $6.99 \%$.

From the point of view of legislative provisions, Romania is best placed on the IPP indicator, being on the 4th place, surpassing Slovakia by $6.99 \%$, and the weakest place on the PR indicator, being also on the 4th place, surpassing Slovakia with $5.79 \%$.

The biggest difference between Romania and the first ranked country within Group 3 is the indicator 1, property rights (PR), where Austria records a percentage of $33.78 \%$ over Romania.

In conclusion, out of the three groups of indicators analyzed, Romania is best placed in terms of Group 3 Legislative provisions, averaging $31.26 \%$ compared to the first rank, followed by group 1 - human resources with an average of $610.24 \%$, and the worst ranking is Group 2 support structure / infrastructure, averaging $1205.63 \%$ compared with the first ranked countries.

The field of innovation and ethical criteria in research should not be neglected [13-25].

\section{References}

1. Zeynep Tuğçe Şimşit, Özalp Vayvay, Özgen Öztürkc, An outline of innovation management process: building a framework for managers to implement innovation, Proceedings of the conference: Procedia - Social and Behavioral Sciences 150, pages 690 - 699 (2014).

2. Tim Stock, Michael Obenaus, Amara Slaymaker, Günther Seliger, A model for the development of sustainable innovations for the early phase of the innovation process, Proceedings of the conference: Procedia Manufacturing 8 pages 215 - 222 (2017).

3. C. I. Ivanov, S. Avasilcai, Performance measurement models: an analysis for measuring innovation processes performance, Proceedings of the conference: Procedia Social and Behavioral Sciences, Challenges and innovations in management and leadership 12th international symposium in management, Volume: 124, Pages: 397-404 (2014).

4. S. Avasilcai, Performance evaluation in Romanian industrial organisations, Proceedings of the conference: Intelligent Manufacturing \& Automation, Annals of daaam for 2007 \& proceedings of the 18th International Daaam Symposium: Intelligent Manufacturing \& Automation: focus on creativity, responsibility, and ethics of engineers, Pages: 27-28 (2007).

5. V. Baesu, C.T. Albulescu, Z.B. Farkas, A. Draghici, Determinants of the high-tech sector innovation performance in the European Union: a review, Proceedings of the conference: Procedia Technology, Volume: 19, Pages: 371-378 (2015).

6. L. Bacali, R.C. Cordos, Intelligent Manufacturing \& Automation, Study on the innovation activity in the 
Romanian firms, Proceedings of the conference: Proceedings of the Romanian Annals Of Daaam For 2007 \& Proceedings Of The 18th International Daaam Symposium: Intelligent Manufacturing \& Automation: Focus On Creativity, Responsibility, And Ethics Of Engineers, Pages: 41-42 (2007).

7. https://tcdata360.worldbank.org/topics/inn?country= $\underline{\mathrm{ROU}}$, accessed in April, 2018.

8. A. Draghici, C.F. Baban, M.L. Gogan, L.V. Ivascu, A Knowledge Management Approach for The University-Industry Collaboration in Open Innovation, Proceedings of the conference: Procedia Economics and Finance, Volume: 23, Pages: 23-32 (2015).

9. N. Barkoczi, L. Bacali, M. Lobontiu, Current status of the interferences between technology diffusin and marketing management, Proceedings of the conference: Management between profit and social responsability, Pages 324-331 (2014).

10. S. Bungau, D. M. Tit, C. Iovan, L. Copolovici, R. Boscencu, G. Cioca, D. Copolovici, New method for Simultaneous Determination of Ascorbic and Acetylsalicylic Acids in effervescent Tablets, Rev Chim. - Bucharest, 68, nr. 11, pages 2495-2503 (2017).

11. M. Badea, C. Chiperea, M. Balan, L. Floroian, P. Restani, J.L. Marty, C. Iovan, D. M. Tit, S. Bungau, N. Taus, New Approaches for Electrochimical Detection of Ascobic Acid, Farmacia, 66, nr. 1, pages 83-90, (2018).

12. D. Mosteanu, G. Barsan, P. Otrisal, L. Giurgiu, R. Oancea, Obtaining the Volatile Oils from Wormwood and Tarragon Plants by a New Microwave Hydrodistilation Method, Revista de Chimie, 68 (11), pages 2499-2502, (2017).

13. F. Blaga, C. Bungau, I. Stanasel, T. Vesseleniy, R. Pancu, D. Craciun, Researches regarding rotarytilting table precision evaluation method using the ball-bar system, Academy Series a-Mathematics Physics Technical Sciences Information Science, Volume: 16 Issue: 4, Pages: 513-521 (2015).

14. C. Bungau, R. Pancu, T. Buidos, Contributions to the Design of the Load Station Concept used at the Flexible Manufacturing Cell, Proceedings of the conference: Engineering Solutions and Technologies in Manufacturing, Volume: 657, Pages: 818-822 (2014).

15. C. Bungau, M. Ganea, R. Pancu, New Tendency of Machine Tool Study Based on Virtual Machining Software Applied at University of Oradea, Industrial and Service Robotics, Volume: 613, Pages: 396-401 (2014).

16. C. Bungau, F. Blaga, C. Gherghea, Kaizen implementation for cost reduction in manufacturing process product "driver control board, Proceedings of the conference: International Conference on Production Research - Regional Conference Africa, Europe and the Middle East, Pages: 55-58 (2014).

17. C. Bungau, I. C. Gherghea, M. Prichici, Value Stream Mapping Analysis, Efficiency Methods of Operational Management, Proceedings of the conference: Twenty Years after: How Management Theory Works, Pages: 188-198 (2010).

18. L. Ivascu, B. Cirjaliu, A. Draghici, , Business model for the university-industry collaboration in open innovation, Proceedings of the conference: Procedia Economics and Finance, Volume: 39, Pages: 674-678 (2016).

19. B.L. Blaga, L. Bacali, R.C. Cordos, Ethics - a priority within the 21 st century's organizations, Proceedings of the conference: 2nd Review of Management and Economic Engineering International Management Conference Pages: 384-389 (2011).

20. G. R. E. Maries, D. Chira, C. Bungau, T. Costea, L. Moldovan, Determining the Influence of the Processing Temperature by Injection and of the Subsequent Pressure on the Surface's Hardness and Indentation Modulus of the Products Made of HDPE, PMMA, PC plus ABS through Nanoindentation - GSeries Basic Hardness Modulus at a Depth Method, Materiale Plastice, Volume: 54 Issue: 2 Pages: 214220 (2017).

21. L. S. Csokmai, R. C. Tarca, C. Bungau, G. Husi, , A Comprehensive Approach to Off-line Advanced Error Troubleshooting in Intelligent Manufacturing Systems, International Journal of Computers Communications \& Control, Volume: 10, Issue: 1, Pages: 30-37 (2015).

22. G. R. E. Maries, D. Chira, C. Bungau, The Influence of Processing Temperatures of (HDPE), (PMMA), (PC plus ABS) on Some Mechanical Properties of Items Obtained Through Injection, Materiale Plastice, Volume: 52, Issue: 4, Pages: 452-456 (2015).

23. D. Chira, G. R. E. Maries, C. Bungau, The Influence of Subsequent Pressure of (HDPE), (PMMA), (PC plus ABS) on Some Mechanical Properties of Items Obtained Through Injection, Materiale Plastice, Volume: 52, Issue: 4, Pages: 572-577 (2015).

24. M. Baban, C. F. Baban, C. Bungau, G. Dragomir, R. M. Pancu, Estimation of the Technical State of Automotive Disc Brakes Using Fuzzy Logic, International Journal of Computers Communications \& Control, Volume: 9, Issue: 5, Pages: 531-538 (2014).

25. T. Vesselenyi, C. Bungau, G. Husi, Research equipment and computation techniques for Intelligent Building applications, Proceedings of the conference: International Symposium on System Integration, Pages: 228-233 (2014). 